\title{
生活習慣病予防の保健指導に必要な能力に関する 市町村保健師の認識
}

\author{
桐 生 育 恵, ${ }^{1}$ 小 林 和 成, ${ }^{2}$ 矢 島 正 榮, ${ }^{2}$ \\ 小 林 亜由美, ${ }^{2}$ 大 野 絢 子, ${ }^{2}$ 佐 藤 由 美 ${ }^{1}$
}

\section{要 旨}

【背景・目的】保健師が認識する保健指導に必要な能力とその修得状況, 修得意欲を明らかにする。【対象と 方法】市町村保健師で, 3 年以上生活習慣病予防に関する保健指導に従事している者を対象に, 自記式質問 紙調査を実施した. 保健指導の能力 6 領域 41 項目について, 能力の必要度, 修得度, 修得意欲を各 5 段階で尋 小た。【結 果】 281 人に質問紙を配布し, 有効回答数は 84 人であった. 能力の必要度が高く修得意欲が高 い項目は，コミュニケーション技術の活用，行動変容ステージに合わせた支援であり，修得度が低い項目は， 科学的根拠に基づいた教材の開発であった. また, 保健指導経験年数等が多い群の方が, 対象者のアセスメン トや生活習慣予防に関する指導の能力の修得度が高かった、【結 語】 能力の必要度や修得意欲が高い能 力, 修得度が低い能力を中心に研修会を企画することと, 保健指導経験などの個々のレベルを考慮して支援 することの必要性が見出された. (Kitakanto Med J 2011；61：37～49)

キーワード：保健師, 生活習慣病, 保健指導

\section{I. 目的}

わが国ではこれまでに生活習慣病に関する一次予防, 二次予防施策を実施してきたが, 改善が見られず医療費 抑制と生活習慣病予防の徹底が緊急課題となっている. その具体的な方略として，メタボリックシンドローム (内臟脂肪症候群) の概念を導入した特定健康診査・特定 保健指導が 2008 年度より開始され，医療保険者に実施 が義務づけられた. ${ }^{1}$ この特定保健指導の対象者 (以下, 対象者とする) は, 特定健康診査の結果, 腹囲が $85 \mathrm{~cm}$ 以 上 (男性) ・90 cm 以上 (女性) の者, または腹囲が $85 \mathrm{~cm}$ 未 満 (男性) ・90 cm 未満 (女性) の者で肥満度を表す指数で ある BMI (Body Mass Index) が 25 以上の者が該当者と なる. そして, 血糖, 脂質, 血圧, 喫煙歴の追加りスクの数 に応じて, 情報提供, 動機付け支援, 積極的支援に階層化 される. 医師・保健師・管理栄養士等の専門家が, 動機付 け支援と積極的支援の対象者と面接を行い，生活習慣の 改善に関わる自主的な取り組みを実施するための行動計
画を設定し，その実践を支援するというものである. 両 者とも行動計画設定の 6 か月後に面接や通信等を利用し 実績評価を行うが，そこでは行動変容状況等の保健指導 の効果が評価される。 そして, 医療保険者は 2012 年度に 扔ける特定保健指導の実施率を $45.0 \%$ 以上にすること, 及び 2012 年度において 2008 年度と比較したメタボリッ クシンドロームの該当者及び予備群の減少率を $10.0 \%$ 以

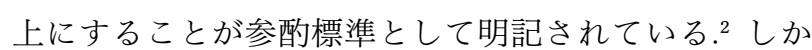
しながら, 特定健康診查・特定保健指導施行後 1 年の段 階で，現場の保健師等にこの制度についての考元を調査 した結果, 特定保健指導の実施率の目標値を達成できる と思うかという問いに対し，「そう思う」，「だいたいそう 思う」と回答した保健師は $13.2 \%$ と低い値を示した. ${ }^{3}$ さ らに, 特定健診・保健指導の実施に関するワーキンググ

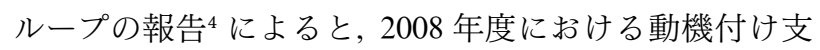
援の実施率は全国平均 17.0\%であり，参酌標準 45.0\%を 超えている市町村は $19.1 \%$ であった. 同じく積極的支援 の実施率に扔いては全国平均は 10.3\%であり, 参酶標準

1 群馬県前橋市昭和町3-39-22 群馬大学医学部保健学科 平成22年11月24日 受付

論文別刷請求先 $\overline{7} 371-8511$ 群馬県前橋市昭和町 3-39-22 群馬大学医学部保健学科 桐生育恵 
を超えている市町村は $7.5 \%$ に過ぎなかった. 参酌標準 を達成するためには，対象者のやる気を引き出し，生活 習慣の改善につながるような保健指導であると同時に， 対象者が保健行動を実践し行動目標を達成することがで きるような継続した関わりが必要である，そのような保 健指導の能力を有するための人材育成は，きわめて重要 な課題である.

保健指導従事者の人材育成においては，従事する者の 認識に即した形で実施することが望ましい 5 が，それに 関する研究はまだ充分にない，

そこで本研究では, 生活習慣病予防の保健指導に従事 している市町村保健師が認識する, 保健指導に必要な能 力とその能力の修得状況及び能力の修得意欲を明らかに することを目的とする. それにより，現状に即した人材 育成の方向性を検討するための, 基礎資料を得ることが できる.

II. 方法

\section{1. 対象}

群馬県内の市町村において, 3 年以上生活習慣病予防 に関わる保健指導業務に従事している保健師. 3 年以上 としたのは, ベナーの看護論 6 の「人前とは, 同じ場所 で $2 \sim 3$ 年くらいの臨床経験がある」を参考に設定した. 市町村保健師の生活習慣病予防に関する保健指導経験年 数は公表されていないため, 2006 年の群馬県看護協会保 健師職能委員会会員名簿より各市町村に所属する保健師 数を把握し, 10 人以上の施設はその数の半数を, 9 人以 下の施設は保健師数に応じて約 $1 \sim 5$ 人を質問紙配布数 とした。

\section{2. 調査方法}

群馬県主催の特定健康診査・特定保健指導の研修会会 場において, 研修会終了後に, 研究の主旨・内容, 及び研 究参加は任意であり参加可否により何ら不利益を受けな いことなどを口頭で説明し，説明文書と質問紙を市町村 単位で配布した。研修会に参加していない市町村に対し ては，保健師主務者宛に研究の主旨・内容等を説明した 文書と質問紙を郵送した。調査対象の保健師には，質問 紙と共に個別の返信用封筒，調査目的等を明示した依頼 文と，倫理的配慮を記した文書を一緒に添付した。対象 の選定及び質問紙の配布は, 各施設の保健師主務者に書 面にて依頼した. 回収は, 協力の得られた保健師個人単 位で郵送にて直接研究者の所属宛に返送することとし た。

\section{3. 調査内容}

厚生労働省健康局から 2007 年 4 月に公表された，『標
準的な健診・保健指導プログラム (確定版)』の『健診・ 保健指導の研修ガイドライン』に記された『研修におい て習得すべき能力』を基に, 保健指導に必要な能力・技術 を抽出した. 能力・技術を抽出する際は, 保健師の専門性 をいかした内容になるよう配慮した。保健指導に必要な 能力の項目は, 健診・保健指導事業の企画・立案・評価の 領域 9 項目, 対象者のアセスメントの領域 6 項目, 生活 習慣に関する指導の領域 12 項目, 自立的な問題解決を 促す支援の領域 8 項目，保健指導の評価に基づく指導方 法の改善の領域 2 項目, 適切な学習教材の選定・開発の 領域 4 項目, 計 6 領域 41 項目とした (以下, 領域を《》, 項目を〈〉で示す). 共同研究者間で, 質問紙の項目が保 健指導の枠組みに属するものであるか検討した，その後, 現場で働く保健師 3 人に意見を求め, 問いの表現形式等 を修正した。

保健指導能力の項目ごとに, (1)この能力・技術は保健 指導場面で不可欠である (以下, 「保健指導能力の必要 度」とする), (2)私はこの能力・技術を修得している (以 下, 「保健指導能力の修得度」とする), (3)私はこの能力・ 技術を強化・修得したい（以下，「保健指導能力の修得意 欲」とする)について，非常に当てはまる】【かなり当て はまる】わりに当てはまる】やや当てはまる】【まり 当てはまらない】の 5 段階で尋ねた。ささに, 保健指導能 力の領域ごとに, 保健指導能力・技術に関する意見・研修 の要望, 特定保健指導に関する意見を自由記載により尋 ねた。

また, 保健師の基本属性として, 性別, 年齢, 保健師経 験年数, 生活習慣病予防に関する保健指導経験年数 (以 下, 保健指導経験年数とする), 1 年間の生活習慣病予防 に関する保健指導人数 (以下, 保健指導人数とする) を尋 ねた。

\section{4. 分析方法}

質問紙の【あまり当てはまらない】から【非常に当て はまる】を $1 \sim 5$ 点とし, 保健指導能力の項目ごとに中 央值を算出した. その後, 保健師の基本属性から, [保健 師経験年数］[保健指導経験年数］[保健指導人数］をグ ループ化変数とし，それぞれの経験別で 3 群に分類した [保健師経験年数］[保健指導経験年数］については, 能力 の発達に関する先行研究6-8 を参考に, 5 年以下, 6-10 年, 11 年以上の 3 群に分類した. [保健指導人数]について は，今回の分析結果を踏まえ代表值を基に 3 群に分類す ることとした. 保健指導能力の項目について, それぞれ のグループ化変数で経験別に比較をする際は, KruskalWallis 検定を用いて 3 群間の比較を行い, 有意差がみら れた場合は Mann-Whitney U 検定を用いて 2 群間の比 較を行った。 
無回答及び不明回答は欠損として取り扱い，有効回答 のみで分析を行った. 統計解析には, SPSS ver. 11.0 for windows を用いた。

\section{5. 調査期間}

2007 年 10 月 12 日 11 月 30 日

\section{6. 倫理的配慮}

調查実施の際は, 各市町村の保健師主務者に対して, 研究の主旨・内容等を書面で説明し, 対象保健師への質 問紙配布等の研究協力依頼を行った. 調查対象の保健師 には, 研究の主旨・内容, 倫理的配慮を記した説明文書を 質問紙に添付し，質問紙の返信をもって協力の同意を得 られたものとした

本調査は, 群馬パース大学研究倫理委員会の審査と承 認を受け, その内容を遵守して実施した.

$$
\text { III. 結果 }
$$

\section{1. 回収状況}

質問紙を 281 人に配布し, 95 人から回答を得た (回収 率 33.8\%). このうち, 基本属性の記入が不備なものや, 回 答の記載が無いものを除外した結果，有効回答数は 84 人であった (有効回答率 $29.9 \%$ ).

\section{2. 対象者の概要}

回答のあった 84 人の性別は，男性 1 人 $(1.2 \%) ， 女$ 性 83 人 $(98.8 \%)$ であった (表 1). 年齢は 26-57 歳で, 平均 $39.9 \pm 8.1$ 歳であった. 保健師経験年数は 3-33 年で, 平均 $15.8 \pm 8.2$ 年であった. 保健指導経験年数は 3-31 年で, 平 均 $11.8 \pm 7.6$ 年であった。保健指導人数については, 1 年 間に 0-450人で, 0 が 20 人 $(25.6 \%)$ と最も多く, 中央值 30 , 平均 $63.8 \pm 95.6$ 人であった.

\section{3. 保健師が認識する保健指導能力の実態}

\section{1 ) 全体の概要}

\section{（1）保健指導能力の必要度}

保健指導能力の全 41 項目において，中央值は 4 から 5 と高い值を示した (表 2). 保健指導能力の領域ごとに見 ると，《健診・保健指導事業の企画・立案・評価》におい ては，中央值は 4 から 5 であり，比較的に 4 が多い傾向 であった。中央值が 5 であった項目は，〈医療関連デー夕 等の分析の視点がわかり，問題を見出すことができる〉 〈問題の中から優先順位の判断ができる〉保健指導の目 標を設定し, 保健指導事業の計画が立てられる〉の 3 項 目であった。

《対象者のアセスメント》においては, 中央值は 4 と 5 が半数であった. 中央值が 5 であった項目は，〈健診結 果・質問票からアセスメントできる〉〈食事摂取状況や食 行動等をアセスメントできる〉健康に対する意識をアセ スメントできる〉の 3 項目であった．また，〈労働内容や 働き方をアセスメントできる〉は，41 項目中【非常に当

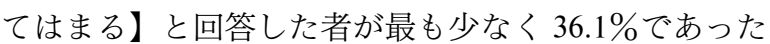

《生活習慣に関する指導》においては, 中央值は 4 と 5 であり，12 項目中 9 項目が 5 であった. 中央值が 5 で あった項目は，〈健診項目に関する基礎知識を理解して いる〉健診結果から身体変化や生活習慣との関連が説明 できる〉〈食事と生活習慣病の関連が説明できる〉〈対象 者にあった食生活の改善が提示できる〉〈身体活動・運動 と生活習慣病の関連が説明できる〉対象者に合った身体 活動・運動の改善が提示できる〉〈たばこと生活習慣病の 関連が説明できる〉〈禁煙支援ができる〉くアルコールと 生活習慣病の関連が説明できる〉であった.

《自立的な問題解決を促す支援》においては, 8 項目の 全てが中央值 5 であった．また〈コミュニケーション技 術を対象者に合わせて活用できる〉は，41 項目中【非常

表 1 対象者の概要

$(\mathrm{n}=84)$

\begin{tabular}{|c|c|c|c|c|}
\hline & & 人 $(\%)$ & 平均值 $\pm \mathrm{SD}$ & 最小-最大 \\
\hline 性別 & $\begin{array}{l}\text { 男性 } \\
\text { 女性 }\end{array}$ & $\begin{array}{rr}1 & (1.2) \\
83 & (98.8)\end{array}$ & & \\
\hline 年齢 & $\begin{array}{l}20 \text { 代 } \\
30 \text { 代 } \\
40 \text { 代 } \\
50 \text { 代 }\end{array}$ & $\begin{array}{rr}8 & (9.5) \\
34 & (40.5) \\
32 & (38.1) \\
10 & (11.9)\end{array}$ & $39.9 \pm 8.1$ 歳 & 26-57 歳 \\
\hline 保健師経験年数 & $\begin{array}{c}5 \text { 年以下 } \\
6-10 \text { 年 } \\
11 \text { 年以上 }\end{array}$ & $\begin{array}{rr}7 & (8.5) \\
21 & (25.6) \\
54 & (65.9)\end{array}$ & $15.8 \pm 8.2$ 年 & 3-33 年 \\
\hline $\begin{array}{l}\text { 生活習慣病予防に関する保健指導経験年数 } \\
\text { (保健指導経験年数) }\end{array}$ & $\begin{array}{c}5 \text { 年以下 } \\
6-10 \text { 年 } \\
11 \text { 年以上 }\end{array}$ & $\begin{array}{ll}18 & (21.4) \\
29 & (34.5) \\
37 & (44.0)\end{array}$ & $11.8 \pm 7.6$ 年 & $3-31$ 年 \\
\hline $\begin{array}{l}1 \text { 年間の生活習慣病予防に関する保健指導人数 } \\
\text { (保健指導人数) }\end{array}$ & $\begin{array}{c}0 \text { 人 } \\
1-30 \text { 人 } \\
31 \text { 人以上 }\end{array}$ & $\begin{array}{ll}20 & (25.6) \\
24 & (30.8) \\
34 & (43.6)\end{array}$ & $63.8 \pm 95.6$ 人 & 0-450人 \\
\hline
\end{tabular}


に当てはまる】と回答した者が最も多く, 71.1\%であっ た.また,〈コミュニケーション技術を対象者に合わせて 活用できる〉〈行動変容ステージに合わせて支援できる〉 〈セルフケア (自己管理) 能力を高める支援ができる〉 は，【非常に当てはまる】【かなり当てはまる】と回答し た者を合わせると $90 \%$ を超えた。

《保健指導の評価に基づく指導方法の改善》において は, 2 項目ともに中央值が 5 であった.また, 〈評価結果か ら, 効果的な保健指導方法を創意工夫できる〉は，【非常 に当てはまる】かなり当てはまる】と回答した者を合わ せると $90 \%$ を超えた。

《適切な学習教材の選定・開発》においては, 中央值は 4 と 5 が半数であった. 中央值が 5 であった項目は, 〈科 学的根拠に基づいた教材を選定できる〉対象者の理解度 に合わせた教材を選定できる〉の 2 項目であった。

\section{(2) 保健指導能力の修得度}

保健指導能力の全 41 項目に扔いて, 中央值は 2 から 3 であった (表 2). 保健指導能力の領域ごとに見ると,《健 診・保健指導事業の企画・立案・評価》においては, 中央 值は 2 と 3 であり, 他の保健指導能力の領域と比べて 2 の割合が多い傾向であった，中央值が 2 であった項目は, 〈ハイリスクアプローチとポピュレーションアプローチ の相乗効果を礼らった事業計画が考元られる〉地域に存 在する社会資源を把握できる〉〈社会資源を活用した健 診・保健指導の実施体制が構築できる〉〈評価指標となる デー夕を分析し，改善すべき事項が判断できる〉〈費用対 効果や最終評価から, 事業全体の評価ができる〉の 5 項 目であった．また〈ハイリスクアプローチとポピュレー ションアプローチの相乗効果を㸚らった事業計画が考光 られる〉は,【非常に当てはまる】と回答した者は一人も いなかった。

《対象者のアセスメント》においては, 中央値はすべて 3であった. しかしながら，〈労働内容や働き方をアセス メントできる〉は,【非常に当てはまる】と回答した者は 一人もいなかった.

《生活習慣に関する指導》においては, 中央值は 2 から 3 であった. 中央值が 2 であった項目は, 〈栄養学および 食事摂取基準, 関連学会ガイドラインの食事療法につい て理解している〉〈運動生理学, 体力測定・評価等に関し て基礎知識を理解している〉〈禁煙支援ができる〉の 3 項 目であった。 また, 〈栄養学扔よび食事摂取基準, 関連学 会ガイドラインの食事療法について理解している〉は, 【非常に当てはまる】と回答した者は一人もいなかった.

《自立的な問題解決を促す支援》においては, 中央值は 2 と 3 であった. 中央值が 2 であった項目は, 〈モチべー ションを高める支援ができる〉の 1 項目のみであった. また,〈コミュニケーション技術を対象者に合わせて活
用できる〉は, 保健指導能力の全 41 項目中【非常に当て はまる】と回答した者が最も多く $10.7 \%$ あった。

《保健指導の評価に基づく指導方法の改善》において は，中央値は 2.5 と 3 であり, 2 項目の回答の割合に大き な違いはみられなかった。

《適切な学習教材の選定・開発》に扔いては, 中央値は 2 と 3 であった. 中央値が 2 であった項目は, 〈科学的根 拠に基づいた教材を選定できる〉科学的根拠に基づいた 教材を必要に応じて開発できる〉対象者の理解度に合わ せた教材を必要に応じて改善・開発できる〉の 3 項目で あった．また，〈科学的根拠に基づいた教材を必要に応じ て開発できる〉に扔いては, 保健指導能力の全 41 項目中 【あまり当てはまらない】と回答した者が最も多く 35.4\%であった.

\section{(3) 保健指導能力の修得意欲}

保健指導能力の全 41 項目に扔いて, 中央值は 1 項目 のみ 3 であり, それ以外は 4 であった (表 2). 保健指導能 力の領域ごとに見ると,《健診・保健指導事業の企画・立 案・評価》においては, 中央值は 3 から 4 で, 〈健診の目

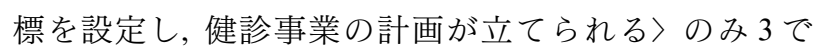
あった. また, 〈健診の目標を設定し, 健診事業の計画が 立てられる〉地域に存在する社会資源を把握できる〉は, 保健指導能力の全 41 項目中【非常に当てはまる】と回答 した者が最も少なく $25.6 \%$ あった。

《対象者のアセスメント》においては, 中央值はすべて 4であり，6 項目の回答の割合に大きな違いはみられな かった。

《生活習慣に関する指導》においては, 中央值はすべて 4 であり，12 項目の回答の割合に大きな違いはみられな かった。

《自立的な問題解決を促す支援》においては, 中央值は すべて 4であった.また,くセルフケア (自己管理) 能力を 高める支援ができる〉は, 保健指導能力の全 41 項目中

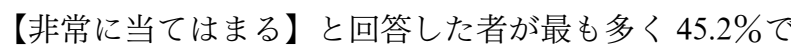
あった，それ以外の〈コミュニケーション技術を対象者 に合わせて活用できる〉行動変容ステージに合わせて支 援できる〉〈自己効力感を高める支援ができる〉〈モチベー ションを高める支援ができる〉継続的なフォローアップ ができる〉の 5 項目に扔いても，【非常に当てはまる】と 回答した者が $40 \%$ を超えた。 〈行動変容ステージに合わ せて支援できる〉は,【非常に当てはまる】【かなり当ては

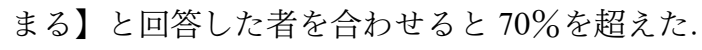

《保健指導の評価に基づく指導方法の改善》において は, 中央値は 4 であり, 2 項目の回答の割合に大きな違い はみられなかった。

《適切な学習教材の選定・開発》においては, 中央值は 4であり，4 項目の回答の割合に大きな違いはみられな 


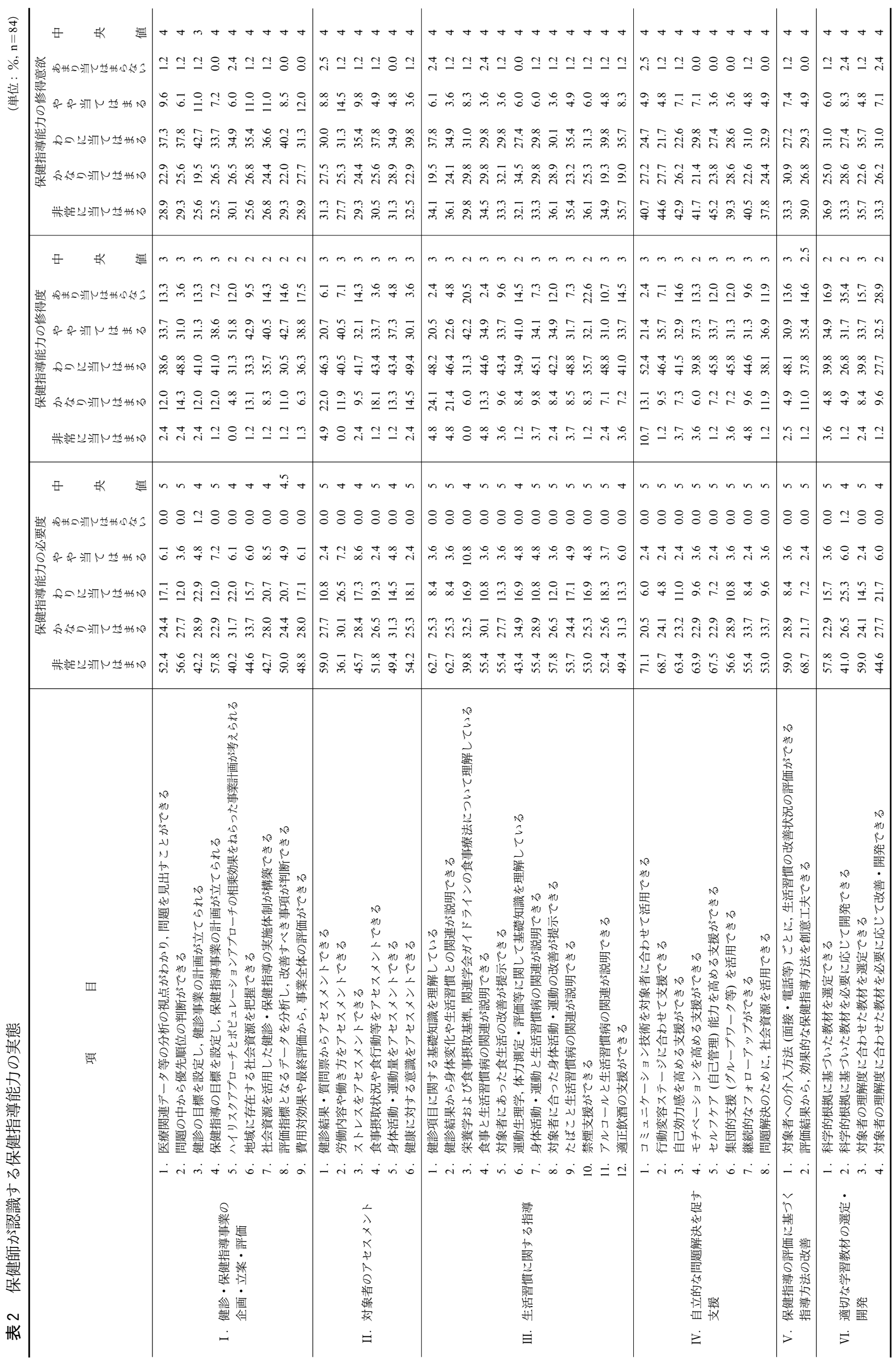


かった.

\section{（4）保健指導能力・技術に関する意見・研修の要望}

質問紙の自由記載から，保健指導能力・技術に関する 意見・研修の要望について, 7 人から回答が得られた (表 3).《健診・保健指導事業の企画・立案・評価》において は，「今まで医療関連データを見たことがない」「データ 分析方法を知りたい」といったデータの解釈や分析方法 に関する記載がみられた、《対象者のアセスメント》にお いては，「参考事例の実習や演習をすると，自己の弱点が 分かる」などの技術の修得方法に関する記載がみられた。 《生活習慣に関する指導》においては，「保健指導の仕方 の研修を希望」といった技術研修の要望に関する記載が みられた、《自立的な問題解決を促す支援》においては, 「相談できる指導者や研修が必要」といった技術研修や支 援を望む記載がみられた。《保健指導の評価に基づく指 導方法の改善》においては,「評価していく基準を明確に
し，その能力を高める研修を希望」といった保健指導の 評価基準に関する記載がみられた。《適切な学習教材の 選定・開発》においては,「市販の教材をうまく利用でき るとよい」といった，教材の活用方法に関する記載がみ られた。

\section{（5）特定保健指導に関する意見}

質問紙の自由記載から，特定保健指導に関する意見に ついて, 21 人から回答が得られた (表 4).「今までの指導 は，継続的支援に欠けていた」といった保健指導に関す ることや，「職場でも学習会を開き，シミュレーションを 行っていく予定」といった職場の体制に関すること,「研 修会を企画する際には，現場実践している人たちの意見 聴取を打願いしたい」といった研修に関すること,「やっ と保健指導が脚光をあび，うれしく思う」といった制度 に関する記載がみられた。

表 3 保健指導能力・技術に関する意見・研修の要望

$(n=7)$

\begin{tabular}{|c|c|}
\hline \multicolumn{2}{|r|}{ 主な内容 } \\
\hline $\begin{array}{l}\text { I . 健診・保健指導事業の企画・立案・ } \\
\text { 評価 }\end{array}$ & $\begin{array}{l}\text { ・とても大切であると思うが, 今まで医療関連データを見たことがない. } \\
\text { ・具体的な事例集の提案や, 考え方を知りたい. } \\
\text { ・データ分析方法を知りたい. }\end{array}$ \\
\hline II. 対象者のアセスメント & $\begin{array}{l}\text { ・学生時代に, 看護診断・地区診断をよく学んでおくことが基礎になる. } \\
\text { ・参考事例の実習や演習をすると, 自己の弱点が分かる. }\end{array}$ \\
\hline III. 生活習慣に関する指導 & $\begin{array}{l}\text { ・マニュアル書が必要 (スタッフが共通に利用できるもの, 教材). } \\
\text { ・各種教材の情報を知りたい. } \\
\text { ・保健指導の仕方の研修を希望. }\end{array}$ \\
\hline IV. 自立的な問題解決を促す支援 & $\begin{array}{l}\text { ・経験を通して身に付けるものであるが, 相談できる指導者や研修が必要. } \\
\text { ・カウンセリング, コーチング技術を, 継続して学ぶことが大切. } \\
\text { ・事例を基にしたグループワーク等, 参加できる研修会. }\end{array}$ \\
\hline $\begin{array}{l}\mathrm{V} . \text { 保健指導の評価に基づく指導方法 } \\
\text { の改善 }\end{array}$ & $\begin{array}{l}\text { ・評価基準が明確にされていないので, 自分の判断基準である. } \\
\text { ・評価していく基準を明確にし, その能力を高める研修を希望. } \\
\text { ・事例を通しての改善. スタッフ間での検討. }\end{array}$ \\
\hline VI. 適切な学習教材の選定・開発 & $\begin{array}{l}\text { ・既存のものも利用したり,まとまっている市販の教材をうまく利用できるとよい. } \\
\text { ・働いていると時間がないので, 業者の開発したものを使用することも多い. } \\
\text { ・教材を選定できる力を養う研修. }\end{array}$ \\
\hline
\end{tabular}

表 4 特定保健指導に関する意見

$(\mathrm{n}=21)$

\begin{tabular}{|c|c|}
\hline \multicolumn{2}{|r|}{ 主な内容 } \\
\hline 保 健 指 導 & 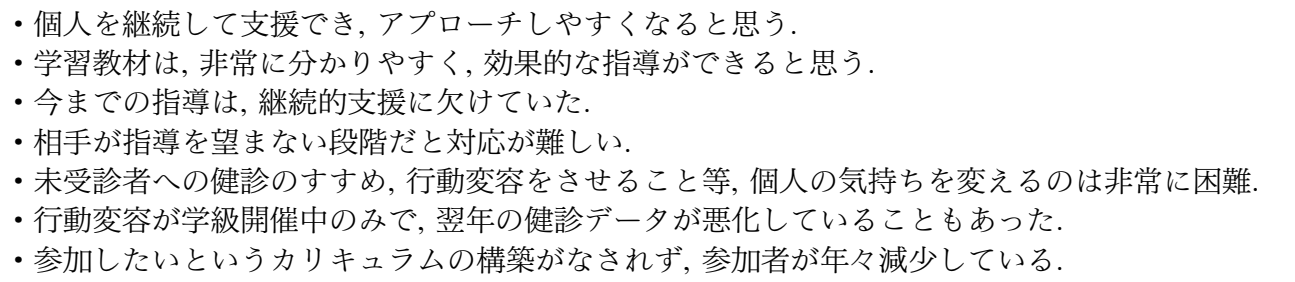 \\
\hline 職場の体制 & $\begin{array}{l}\text { ・必要最低限を抑えるために, 職場でも学習会を開き, シュミレーションを抗こなっていく予定. } \\
\text { ・対象数と指導可能人数, 効果が未知であり, 計画を立てるのが難しい. } \\
\text { ・予防することがでをる人から関わる仕組みや, 科学的根拠に基づいた資料開発に取り組み始めた }\end{array}$ \\
\hline 研 & $\begin{array}{l}\text { ・グループワークの進め方や, 面接技術, 教材の選び方等の研修が必要. } \\
\text { ・研修会を企画する際には, 現場実践している人たちの意見聴取をお願いしたい. } \\
\text { •今まで, 生活習慣病予防のための保健指導研修が少なかった. }\end{array}$ \\
\hline 制 度 & $\begin{array}{l}\text { ・やっと保健指導が脚光をあび, うれしく思う. } \\
\text { ・膨大な対象者の一部の方にしか, 対応できていないのではないかと思う. }\end{array}$ \\
\hline
\end{tabular}


表 5 保健指導能力に関する認識の比較一保健指導能力の必要度

$(\mathrm{n}=84)$

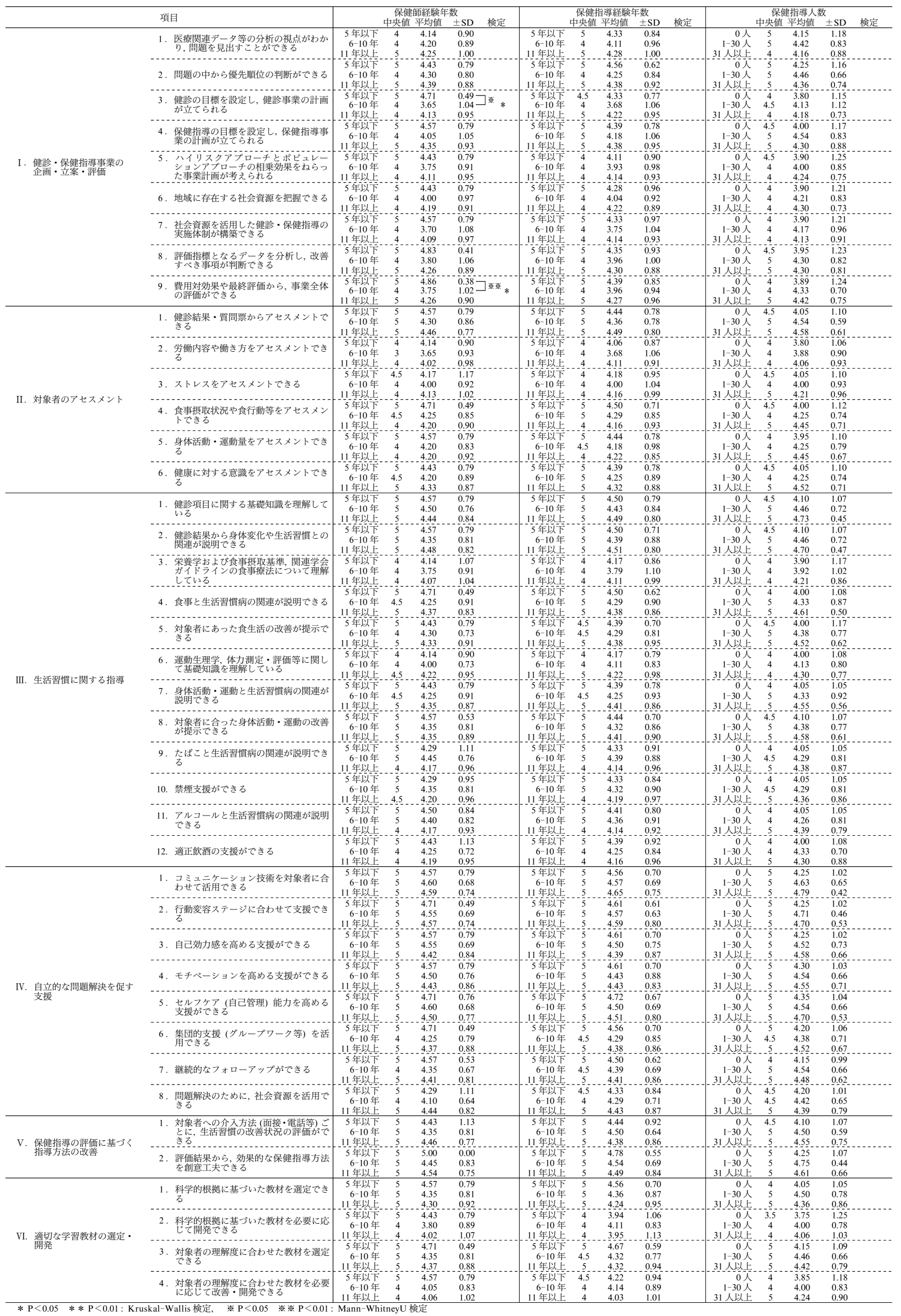


表 6 保健指導能力に関する認識の比較一保健指導能力の修得度

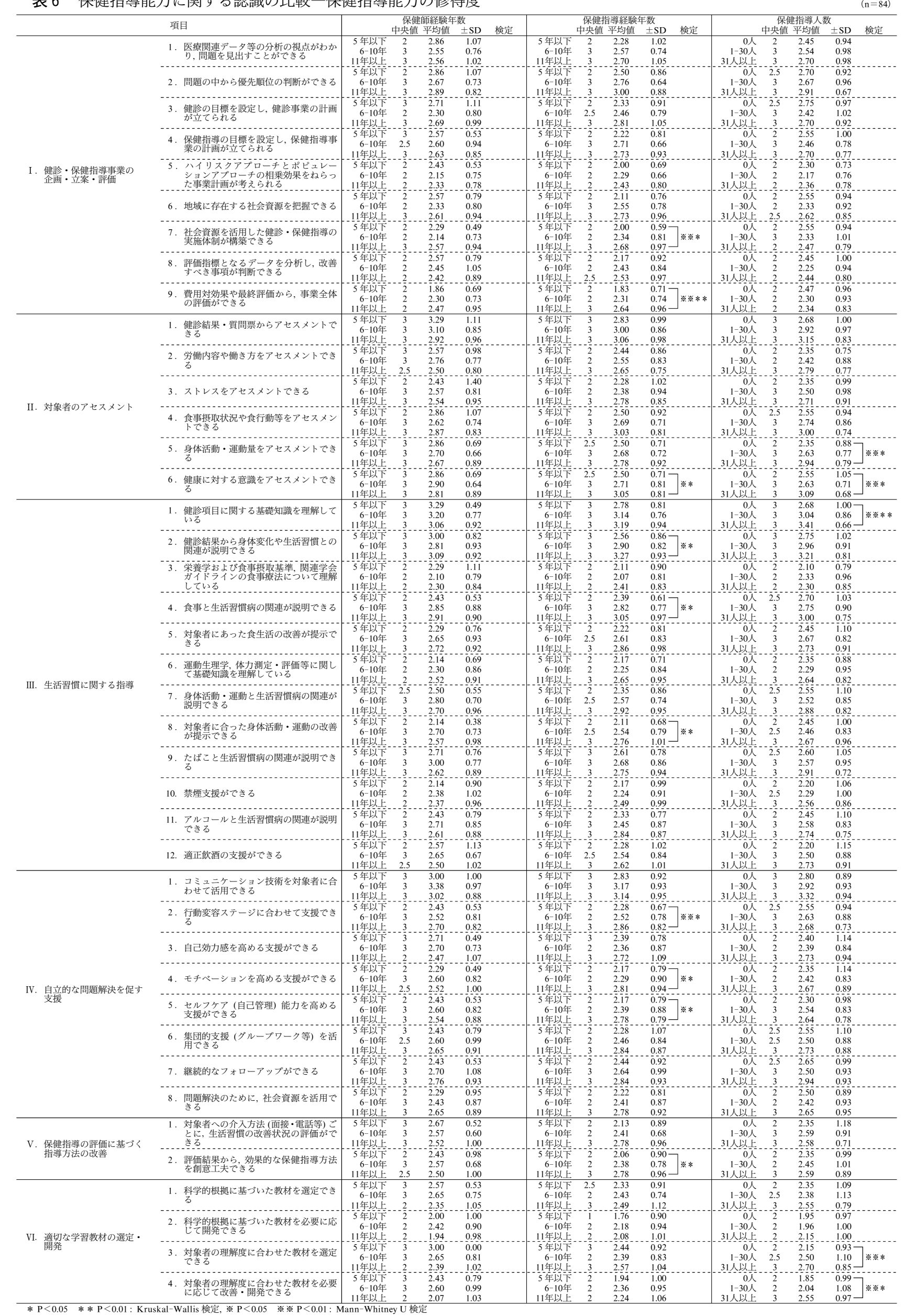


表 7 保健指導能力に関する認識の比較一保健指導能力の修得意欲

\begin{tabular}{|c|c|c|c|c|c|c|c|c|}
\hline & 項目 & & & 需経駼 & \pm SD & 検定 & & \\
\hline & 1. 医療閵連デー多等の分析の視点がかか & $\begin{array}{l}5 \text { 年以下 } \\
6-10 \text { 年 } \\
\end{array}$ & $\begin{array}{l}3 \\
3 \\
4\end{array}$ & $\begin{array}{l}3.71 \\
3.52 \\
3.72\end{array}$ & $\begin{array}{l}0.95 \\
1.12 \\
1.03\end{array}$ & & $\begin{array}{l}5 \text { 年以下 } \\
6 \text {-10年 } \\
\end{array}$ & $\begin{array}{l}4 \\
3 \\
4\end{array}$ \\
\hline & & 5年以市 & $-\frac{4}{4}-$ & 4.00 & 1.00 & & - 5 年以宗 & $-\frac{4}{4}-$ \\
\hline & 2. 問題の中から優先順位の判断ができる & $\begin{array}{r}\text { 6-10年 } \\
\text {-11年以上 }\end{array}$ & $\begin{array}{r}4 \\
4 \\
-4\end{array}$ & $\begin{array}{l}3.70 \\
3.72\end{array}$ & $\begin{array}{l}1.08 \\
0.97\end{array}$ & & $\begin{array}{r}\text { 6-10年 } \\
11 \text { 年以上 }\end{array}$ & $\begin{array}{r}4 \\
4 \\
-\end{array}$ \\
\hline & $\begin{array}{l}\text { 3. 健診の目標を設定し, 健診事業の計画 } \\
\text { が立らるれ }\end{array}$ & 6-10年 & $\begin{array}{l}-7 \\
3 \\
3\end{array}$ & $\begin{array}{r}4.00 \\
3.33 \\
3.58\end{array}$ & $\begin{array}{l}1.00 \\
1.11 \\
0.99\end{array}$ & & $\begin{array}{l}5 \text { 年以 } \\
6-10 \text { 年 } \\
\end{array}$ & $\begin{array}{c}3.0 \\
3 \\
4\end{array}$ \\
\hline & 4. 保健指導の目標を設定し, 保健指導事 & - 5 年以市 & $-\frac{3}{4}-$ & --3.38 & $-0.99-$ & & - 5 年产市 & $-\frac{4}{4}-$ \\
\hline & 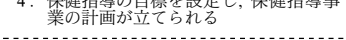 & $\begin{aligned} \text { 6-10年 } \\
11 \text { 年以上 }\end{aligned}$ & $\begin{array}{r}4 \\
4 \\
-4\end{array}$ & $\begin{array}{r}3.71 \\
3.79\end{array}$ & $\begin{array}{l}1.06 \\
0.95\end{array}$ & & $\begin{aligned} \text { 6-10年 } \\
11 \text { 年以上 }\end{aligned}$ & $\begin{array}{l}4 \\
4\end{array}$ \\
\hline I. 健䇏・保健指導事業の & & 5 年以下 & 4 & 4.29 & 0.76 & & 5 年以下 & 4 \\
\hline 企画・立案·評価 & 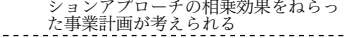 & $\begin{aligned} \begin{array}{l}6-10 \\
\text {.11年 }\end{array} \\
\end{aligned}$ & $\begin{array}{r}4 \\
4 \\
-\end{array}$ & $\begin{array}{r}3.48 \\
3.77\end{array}$ & $\begin{array}{r}1.25 \\
0.95\end{array}$ & & $\begin{array}{r}\text { 6-10年 } \\
11 \text { 年以上 }\end{array}$ & $\begin{array}{r}4 \\
4 \\
-\end{array}$ \\
\hline & & 5 年以实 & 4 & 4.14 & 0.69 & & 一年以宗 & $-\frac{1}{4}$ \\
\hline & 6. 地域に存在する社会資源を把握できる & $\begin{array}{l}\text { 6-10年 } \\
11 \text { 年以上 }\end{array}$ & $\begin{array}{c}3.5 \\
3\end{array}$ & $\begin{array}{l}3.45 \\
3.62\end{array}$ & $\begin{array}{l}1.15 \\
1.00\end{array}$ & & $\begin{array}{l}\text { 6-10年 } \\
11 \text { 年以上 }\end{array}$ & $\begin{array}{l}3 \\
4\end{array}$ \\
\hline & & 一年以宗 & $-\frac{2}{4}$ & -4.14 & 0.69 & & 5 年以市 & $-\frac{7}{4}$ \\
\hline & 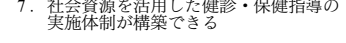 & $\begin{array}{l}\text { 6-10年 } \\
11 \text { 年以上 }\end{array}$ & $\begin{array}{l}3 \\
3\end{array}$ & $\begin{array}{l}3.30 \\
3.68\end{array}$ & $\begin{array}{l}1.17 \\
1.00\end{array}$ & & $\begin{array}{l}\text { 6-10年 } \\
11 \text { 年以上 }\end{array}$ & $\begin{array}{l}3 \\
4\end{array}$ \\
\hline & & 一年以宗 & $-\frac{2}{4}$ & 4.00 & 0.82 & & 5 年以宗 & $-\frac{7}{4}$ \\
\hline & 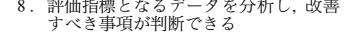 & $\begin{array}{l}\text { 6-10年 } \\
11 \text { 年以上 }\end{array}$ & $\begin{array}{l}3 \\
4\end{array}$ & $\begin{array}{l}3.45 \\
3.77\end{array}$ & $\begin{array}{l}1.00 \\
0.99\end{array}$ & & $\begin{array}{l}\text { 6-10年 } \\
11 \text { 年以上 }\end{array}$ & $\begin{array}{l}3 \\
4\end{array}$ \\
\hline & & 5年以下 & $-\frac{7}{4}$ & 4.00 & 0.82 & & 5年以市 & $-\frac{7}{4}$ \\
\hline & $\begin{array}{l}\text { 9. 費用㸚効果や最終評価から, 事業全体 } \\
\text { 栖ができる }\end{array}$ & 6-10年 & 3 & 3.48 & 1.03 & & 6-10年 & 3 \\
\hline & & 5 年以下 & $\frac{4}{5}$ & $\frac{3.19}{4.43}$ & $\frac{1.03}{0.79}$ & & $\begin{array}{l}11 \text { 年以上 } \\
5 \text { 年以下 }\end{array}$ & $\frac{4}{4}$ \\
\hline & 1.健診結果・質問票からアセスメントで & 6-10年 & 4 & 3.67 & 1.14 & & 6-10年 & 4 \\
\hline & & - 5 年以市 & $-\frac{4}{5}-$ & -4.00 & $1.41^{-}$ & & - - - & $-\frac{4}{4}-$ \\
\hline & 2. 学㗢内容や働き方をアセスメントでぎ & 6-10年 & 3 & 3.35 & 1.09 & & $6-10$ 年 & 3 \\
\hline & & -11年以上 & 4 & -3.67 & 1.03 & & 11年以上 & 4 \\
\hline & 3、ストレスをアセスメントできる & 5 年以下 & 5 & 4.14 & 1.21 & & 5 年以下 & 4 \\
\hline II. 対象者のアセスメント & 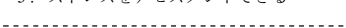 & 11年以上 & 4 & 3.72 & $\begin{array}{l}0.94 \\
1.04\end{array}$ & & $\begin{array}{l}\text { 11-104 } \\
11 \text { 年以上 }\end{array}$ & 4 \\
\hline 11. 对家者的广大メン下 & 行陲等萑 & 5 年以下 & 5 & 4.29 & 0.95 & & 5 年以下 & 4 \\
\hline & 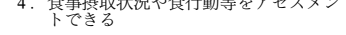 & 6-10年 & 3.5 & 3.65 & 0.88 & & 6-10年 & 3 \\
\hline & & - 5 年以宗 & $-\frac{7}{4}$ & -4.29 & -0.76 & & - & $-\frac{7}{4}-$ \\
\hline & 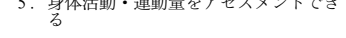 & 6-10年 & $\begin{array}{l}4 \\
4\end{array}$ & 3.76 & 1.00 & & 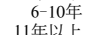 & 3.0 \\
\hline & & - 5 年以宗 & $-\frac{7}{4}$ & -4.14 & -0.90 & & 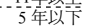 & $-\frac{7}{4}-$ \\
\hline & 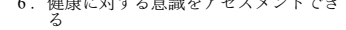 & 6-10年 & 4 & 3.76 & 0.94 & & 6-10年 & 3 \\
\hline & & 11年以上 & 4 & 3.79 & 1.01 & & 11年以上 & 4 \\
\hline & & 5 年以下 & 5 & 4.29 & 1.11 & & 5 年以下 & 5 \\
\hline & 1. 蜼子 & $\begin{aligned} \text { 6-10年 } \\
\text {-11年以上 }\end{aligned}$ & $\begin{array}{r}3 \\
4 \\
-\end{array}$ & $\begin{array}{r}3.55 \\
3.77 \\
\end{array}$ & $\begin{array}{l}1.15 \\
1.03\end{array}$ & & $\begin{array}{r}\text { 6-10年 } \\
11 \text { 年以上年 }\end{array}$ & $\begin{array}{r}3 \\
4 \\
-\end{array}$ \\
\hline & 2. 健診結果から身体変化や生活習慣との & 5 年以下 & 5 & 4.57 & 0.53 & & 5 年以市 & 4 \\
\hline & 関連が説明できる & $\begin{array}{r}\text { 6-10年 } \\
11 \text { 年以上 }\end{array}$ & $\begin{array}{c}3.5 \\
4\end{array}$ & $\begin{array}{l}3.80 \\
3.85\end{array}$ & $\begin{array}{l}0.89 \\
1.04\end{array}$ & & $\begin{array}{r}\text { 6-10年 } \\
11 \text { 年以上 }\end{array}$ & $\begin{array}{l}3 \\
4\end{array}$ \\
\hline & 3. 栄養学拈よび食事摂取基準, 関連学会 & 5 年以下 & 4 & 4.14 & 0.69 & & 5 年以下 & 4 \\
\hline & 势皁ドラインの食事療法について理解 & 6-10年 & 3 & $\begin{array}{l}3.43 \\
3.87\end{array}$ & 1.21 & & 6-10年 & 3 \\
\hline & & - 5 年以市 & $-\frac{4}{4}-$ & $-\frac{3.01}{4.29}$ & 0.76 & & - 5 年以宗 & $-\frac{4}{4}-$ \\
\hline & 4. 食事と生活習慣病の関連が説明できる & 6-10年 & 4 & 3.86 & 0.85 & & 6-10年 & 3 \\
\hline & & $-\frac{11}{5}$ 年以年以 & $-\frac{4}{4}-$ & $-\frac{3.85}{4.29}$ & -1.09 & & - - & -4.0 \\
\hline & $\begin{array}{l}\text { 5. 対象者にあった食生活の改善が提示で } \\
き る\end{array}$ & 6-10年 & 4 & 3.86 & 0.91 & & 6-10年 & 4.0 \\
\hline & & - 5 年以市 & $-\frac{4}{4}-$ & $-\frac{3.91}{4.29}$ & $-0.98-76$ & & 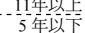 & $-\frac{4}{4}-$ \\
\hline & 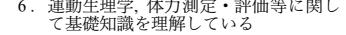 & 6-10年 & 4 & 3.71 & 0.90 & & 6-10年 & 4 \\
\hline III. 生活習慣化関する指導 & & - 5 年以市 & $-\frac{4}{4}-$ & $-\frac{3.96}{4.14}$ & $-0.93-3$ & & $-\frac{11}{5}$ 年以㐋 & $-\frac{4}{4}-$ \\
\hline & 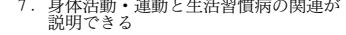 & 6-10年 & 4 & 3.67 & 1.06 & & 6-10年 & 4.0 \\
\hline & & - $-\frac{114}{5}$ 年以卡 & $-\frac{4}{4}-$ & $-\frac{3.91}{4.29}$ & $-\frac{1.00}{0.76}$ & & $-\frac{11}{5}$ 年以点 & $-\frac{4}{4}-$ \\
\hline & 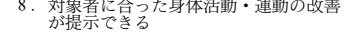 & $\begin{array}{l}\text { 6-10年 } \\
11 \text { 年以上 }\end{array}$ & 3.5 & 3.80 & 0.89 & & 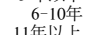 & 4 \\
\hline & & - 5 年以宗 & $-\frac{4}{4}$ & -4.14 & 1.07 & & - 5 年以管 & $-\frac{4}{4}-$ \\
\hline & 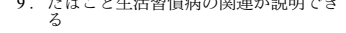 & 6-10年 & 4 & 3.95 & 0.89 & & 6-10年 & 4 \\
\hline & & - $\frac{11 \text { 年以步 }}{5}$ & $-\frac{4}{4}-$ & $\begin{array}{rl}-3.79 & -79 \\
4.29 & 0\end{array}$ & $\begin{array}{c}1.04 \\
-0.76\end{array}$ & & $\begin{array}{l}11 \text { 年以卡 } \\
\text { 年以卡 }\end{array}$ & $-\frac{4}{4}-$ \\
\hline & 10、禁煙支援ができる & 6-10年 & 4 & 3.85 & 0.93 & & 6-10年 & 4 \\
\hline & & 11年以上 & 4 & 3.85 & 1.07 & & 11年以上 & 4. \\
\hline & 11.アルコールと生活習慣病の関連が説明 & 5年以下 & 4 & 4.00 & 1.00 & & 5 年以下 & 4 \\
\hline & 11. できる & $\begin{aligned} \text { 6-10年 } \\
11 \text { 年以上 }\end{aligned}$ & $\begin{array}{c}3.5 \\
4\end{array}$ & $\begin{array}{l}3.85 \\
3.78\end{array}$ & $\begin{array}{l}0.93 \\
1.06\end{array}$ & & $\begin{array}{l}\text { 6-10年 } \\
11 \text { 年以上 }\end{array}$ & $\begin{array}{l}4 \\
4\end{array}$ \\
\hline & & 一年以穴 & $5-$ & -4.43 & -0.79 & & - 5 年以宗 & $-\frac{1}{4}$ \\
\hline & 12. 適正欴酒の支援がてきるる & 6-10年 & 3 & 3.67 & 1.02 & & 6-10年 & 3 \\
\hline & & 11 年以上 & 4 & 3.76 & 1.10 & & 11 年以上 & 4 \\
\hline & & 5 年以下 & 5 & 4.43 & 0.79 & & 5 年以下 & 5 \\
\hline & 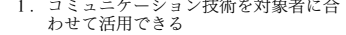 & 6-10年 & 4 & 3.80 & 1.06 & & 6-10年 & 4 \\
\hline & & $-\frac{11}{5}$ 年以上 & $-\frac{4}{5}-$ & $-\frac{3.98}{4.71}$ & $-1.08-$ & & $\begin{array}{l}11 \text { 年以卡 } \\
-\frac{1}{2} \text { 年以卡 }\end{array}$ & $-\frac{4}{5}-$ \\
\hline & 2.行動変容ステージに合わせて支援でき & 6-10年 & 4 & 4.00 & 1.08 & & 6-10年 & 4 \\
\hline & & $-\frac{11}{5}$ 年以上 & $-\frac{4}{5}-$ & $\begin{array}{rl} & 4.04 \\
4.57 & 04\end{array}$ & $\begin{array}{l}0.99 \\
-0.53\end{array}$ & & $-\frac{11}{5}$ 年以上卡以 & $-\frac{4}{5}-$ \\
\hline & 3. 自己効力感を高める支援ができる & 6-10年 & 4 & 4.05 & 1.07 & & 6-10年 & 4 \\
\hline & -...... & - $-\frac{11}{5}$ 年以点 & $-\frac{4}{5}-$ & $-\frac{3.94}{4.14}$ & $-\frac{1.05}{-121}$ & & -11年以步 & $-\frac{4}{5}-$ \\
\hline & 4. モチベーションを高める支援ができる & 6-10年 & 4 & $\begin{array}{r}4.14 \\
4.00\end{array}$ & $\begin{array}{l}1.21 \\
1.05\end{array}$ & & $\begin{array}{l}3 \text { 年1 } \\
6-10 \text { 年 }\end{array}$ & 4 \\
\hline IV. 息咅的な問題解決を促す & - & 11年以上 & $4-$ & 3.94 & 0.98 & & 11年以上 & \\
\hline & 5.七ルフケア (自己管理) 能力を高める & 5 年以下 & $55^{-}$ & 4.43 & $0.79^{-}$ & & 5 年舵 & $-5-$ \\
\hline & 支援ができる & $\begin{array}{r}\text { 6-10年 } \\
11 \text { 年以上 }\end{array}$ & 4 & $\begin{array}{l}4.10 \\
4.07\end{array}$ & $\begin{array}{l}1.00 \\
0.93\end{array}$ & & $\begin{array}{l}\text { 6-10年 } \\
11 \text { 年以上 }\end{array}$ & $\begin{array}{l}4 \\
4\end{array}$ \\
\hline & 6. 集団的支援 (グループワーク等) を活 & 5 年以下 & 5 & 4.43 & 0.79 & & 5 年放下 & $-\frac{1}{5}$ \\
\hline & 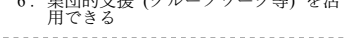 & $\begin{aligned} \text { 6-10年 } \\
11 \text { 年以上 }\end{aligned}$ & 4 & $\begin{array}{l}4.00 \\
4.00\end{array}$ & $\begin{array}{l}0.95 \\
0.91\end{array}$ & & $\begin{array}{l}\text { 6-10年 } \\
11 \text { 年以上 }\end{array}$ & $\begin{array}{c}4.0 \\
4\end{array}$ \\
\hline & & 5 年以市 & $-\frac{1}{5}$ & -4.57 & 0.79 & & 5 年 & $-\frac{1}{5}$ \\
\hline & 7. 継続的なフォローアップができる & $6-10$ 年 & 4 & 3.81 & 1.03 & & $6-10$ 年 & 3.0 \\
\hline & ....... & 11年 & & 3.94 & 1.02 & & 11年以上 & 4 \\
\hline & 8 問㒹解決のために社会盗源を活用で & 5 年以下 & 55 & 4.43 & $0.79^{-}$ & & 5 年以市 & 4.5 \\
\hline & 8.問題解决のために, 社会資源を活用で & 6-10年 & 4 & 3.80 & 1.06 & & 6-10年 & 3 \\
\hline & & 11 年以上 & 4 & 3.94 & 0.93 & & 11年以上 & 4 \\
\hline & 1. 対象者への介入方法 $($ 面接・電話等) ご & 5 年以下 & 4 & 4.00 & 1.10 & & 5 年以下 & 4 \\
\hline & 評価がで & 6-10年 & 4 & 3.85 & 0.88 & & 6-10年 & 4 \\
\hline 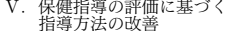 & -.... & 11年 & $-\frac{4}{5}-$ & 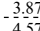 & -1.06 & & 11年以上 & $-\frac{4}{5}-$ \\
\hline & 2. 評価結果から, 効果的な保健指導方法 & $\begin{array}{l}5 \text { 年以下 } \\
6-10 \text { 年 }\end{array}$ & $\begin{array}{l}5 \\
4\end{array}$ & $\begin{array}{l}4.57 \\
3.95\end{array}$ & $\begin{array}{l}0.79 \\
0.89\end{array}$ & & $\begin{array}{c}5 \text { 年以下 } \\
6-10 \text { 年 }\end{array}$ & $\begin{array}{l}5 \\
4\end{array}$ \\
\hline & を創 & 11年 & 4 & 3.94 & 0.97 & & 11 年以上 & 4 \\
\hline & & & 4 & & 0.90 & & 5 年以下 & 5 \\
\hline & 1. 科学的根拠に基づいた教材を選定でき & 6-10年 & 4 & 3.76 & 1.04 & & 6-10年 & 4 \\
\hline & & $-\frac{11}{5}$ 年1 & 4 & 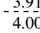 & $\begin{array}{lll}1.03 \\
1.15\end{array}$ & & 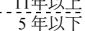 & $-\frac{4}{4}-$ \\
\hline & 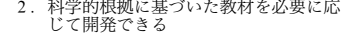 & 6-10年 & 3 & 3.57 & 0.98 & & 6-10年 & 4 \\
\hline VI. 適䍿登 & & - $\frac{11 \text { 年以上 }}{5}$ 年以市 & $-\frac{4}{5}-$ & $-\frac{3.89}{4.43}$ & $-\frac{1.09}{0.09}$ & & $\begin{array}{l}11 \text { 年以上 } \\
5 \text { 年以卡 }\end{array}$ & $-\frac{4}{5}$ \\
\hline & 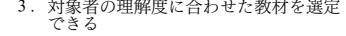 & 6-10年 & 3 & 3.71 & 0.96 & & $\begin{array}{l}\text { 6-10年 } \\
-11 \text { 年以上 }\end{array}$ & 4.0 \\
\hline & & $\frac{112-1}{5}$ & $5^{-}$ & 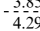 & $\begin{array}{l}1.04 \\
-0.95\end{array}$ & & $-\frac{11}{5}$ 年以贡 & -4.0 \\
\hline & 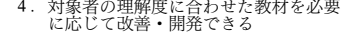 & 6-10年 & 3 & 3.52 & 0.98 & & $\begin{array}{l}\text { 6-10年 } \\
-10\end{array}$ & 4 \\
\hline & 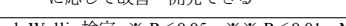 & & 4 & & 1.09 & & 11年以上 & \\
\hline
\end{tabular}




\section{2 ）保健指導能力に関する認識の比較}

保健指導能力の項目について, [保健師経験年数 ] [保 健指導経験年数］[保健指導人数］ごとに, 経験別で比較 をした，その際，[保健指導人数］については, 最頻值 20, 中央值 30 という今回の調査結果を踏まえ, 0 人, 1-30人, 31 人以上の 3 群に分類した.

\section{(1) 保健指導能力の必要度}

保健指導能力の必要度では, [保健師経験年数] におい て, 《健診・保健指導事業の企画・立案・評価》の 2 項目 で有意差がみられた (Kruskal-Wallis 検定)（表 5).いず れの項目も, 5 年以下の群が 6-10 年の群よりも点数が高 いという結果であった (Mann-Whitney U 検定).

\section{(2) 保健指導能力の修得度}

保健指導能力の修得度では, [保健指導経験年数] にお いて, 《健診・保健指導事業の企画・立案・評価》の 2 項 目,《対象者のアセスメント》の 1 項目, 《生活習慣に関す る指導》の 3 項目, 《自立的な問題解決を促す支援》の 3 項目,《保健指導の評価に基づく指導方法の改善》の 1 項 目, 計 10 項目で有意差がみられた (Kruskal-Wallis 検定) (表 6). いずれの項目も, 11 年以上の群が 5 年以下の群よ りも点数が高いという結果であった (Mann-Whitney U 検定).

[保健指導人数］に扔いて, 《対象者のアセスメント》 の 2 項目, 《生活習慣に関する指導》の 1 項目, 《適切な学 習教材の選定・開発》の 2 項目, 計 5 項目で有意差がみら れた (Kruskal-Wallis 検定).いずれの項目も, 31 人以上 の群が 0 人の群よりも点数が高いという結果であった (Mann-Whitney U 検定).

\section{（3）保健指導能力の修得意欲}

保健指導能力の修得意欲では, [保健指導人数]におい て,《生活習慣に関する指導》の 1 項目のみ有意差がみら れた (Kruskal-Wallis 検定) (表 7). 31 人以上の群が 0 人 の群よりも点数が高いという結果であった（MannWhitney U 検定).

\section{IV. 考察}

\section{1. データの適切性}

質問紙の回答数が 84 人と少なかったことに関しては, 対象の基準を 3 年以上生活習慣病予防㳊関わる保健指導 業務に従事している保健師としたため, 正確な人数の把 握が困難であったこと，特定保健指導に関心を持ってい る者のみが回答したというバイアスが考えられる. 特定 健康診査・特定保健指導の体制が整備された後, 標本数 を増やして検討する必要がある。

\section{2. 保健指導に必要な能力と育成方法}

1 ) 保健師が認識する保健指導能力と強化すべき保健指 導能力

人材育成のための支援を考えるとき，教育者側が強化 する必要があると考元る内容と, 対象者側が修得したい と考える内容は必ずしも一致するとは限らないため, 双 方を反映した内容であることが望ましい.9 質問紙の自 由記載から, 特定保健指導に関する意見の中で, 「研修会 を企画する際には，現場実践している人たちの意見聴取 をお願いしたい」といった声もあり，現場の状況をふま えながら現状に即した人材育成の方向性を検討すること が大切である。

今回の結果から，保健指導能力を強化する優先順位が 高いものとしては, 以下のことが考元れた。保健指導 能力の必要度が高く修得意欲が高い《自立的な問題解決 を促す支援》と,《保健指導の評価に基づく指導方法の改 善》.また, 保健指導能力の修得度が低い《適切な学習教 材の選定・開発》, そして保健指導能力の必要度, 修得度, 修得意欲ともに比較的低い值を示した《健診・保健指導 事業の企画・立案・評価》が考えられた．以下，それぞれ の保健指導能力について述べる.

\section{（1） 自立的な問題解決を促す支援}

自立的な問題解決を促す支援について，保健指導能力 として必要と考える者が多く, 修得したいと考える者が 多かった。特定保健指導の対象者は基本的には自覚症状 の無い者であり，そのような対象者が生活習慣を見直し て行動変容をすることが保健指導者には求められる。 そ のためには，対象者との信頼関係の構築が基盤となり， その上で対象者の生涯にわたるセルフケア能力を高める ことが重要である.10-12 このようなことから，〈コミュニ ケーション技術を対象者に合わせて活用できる〉や〈セ ルフケア (自己管理) 能力を高める支援ができる〉につい ての保健指導能力が必要と考元, 修得を望んでいるので はないかと考元る.また，特定保健指導では 5 つのス テージ (無関心期・関心期・準備期・実行期・維持期) ご とに支援方法を変え，ステージが改善していけるように 支援することが明記されている. ${ }^{13}$ このことから, 各行動 変容ステージに合わせた支援が意識づき，〈行動変容ス テージに合わせて支援できる〉保健指導能力が必要と考 え, 修得を望んでいるのではないかと考える.

\section{（2）保健指導の評価に基づく指導方法の改善}

保健指導の評価に基づく指導方法の改善について，保 健指導能力として必要と考える者が多く, 修得したいと 考元る者も比較的多かった，この背景には，従来は保健 指導の実施量をその評価指標としていたことが多く, 保 健指導を行った効果までは求められてはいかったことの 影響が推測される. 今回の調査では，〈評価結果から, 効 
果的な保健指導方法を創意工夫できる〉保健指導能力を 修得している者はそれほど高くはないが, 特定保健指導 導入後は, 特定健康診査の結果やレセプト等から保健指 導の効果が評価できるため，それらを活用しょり効果的 な保健指導方法について検討することが重要となる. 質 問紙の保健指導能力・技術に関する意見や研修の要望の 自由記載において，「評価していく基準を明確にし，その 能力を高める研修を希望」といった声も聞かれたことか ら, 保健指導の評価についての研修会の企画も必要であ る.

\section{（3） 適切な学習教材の選定・開発}

〈科学的根拠に基づいた教材を必要に応じて開発でき る〉について，この保健指導能力を修得している者は少 なかった。これは, 従来の保健指導では対象者に一律な 教材を用い，新たに教材を開発することはあまりされて はこなかったため,この能力を修得している者が少ない のではないかと考元る。しかしながら，科学的根拠に基 づいた教材は, 対象者が生活習慣を変える動機づけとし て有用であり，行動変容につながることが期待される， このようなことから, この保健指導能力は保健指導に とって大変重要であり, この保健指導能力の強化が必要 である。

\section{（4）健診・保健指導事業の企画・立案・評価}

健診・保健指導事業の企画・立案・評価について, 保健 指導能力として必要と考える者や修得したいと考える者 は比較的少なく, 修得している者も少なかった，これは， 担当業務の状況によって直接的な関わりの少ないこと や，日常的に関わりの少ない業務であることの影響が考 えられ, 先行研究と同様の結果となった ${ }^{7}$ しかしながら, この項目は特定健康診查・特定保健指導の枠組みに扔い て, 保健師に期待される業務のひとつである. ${ }^{14}$ 保健指導 に従事する医療従事者の中で, 保健師としての専門性を いかすためにも，ぜひとも強化したい保健指導能力であ る. 質問紙の保健指導に必要な能力・技術に関する意見・ 研修の要望で,「今まで医療関連デー夕を見たことがな い」「デー夕分析方法を知りたい」といった声も聞かれた ことから，保健事業の計画策定に関わる者を対象とする など, 対象を限定した研修会の企画が必要である.

\section{2 ）経験を考慮する能力}

保健指導能力に関する認識を経験別に比較した結果, 保健指導能力の必要度において, 《健診・保健指導事業の 企画・立案・評価》が, 保健師経験年数の 5 年以下の群が, 6-10 年の群よりも点数が高いという結果であった。これ は, 3-5 年は一通りの業務を覚元, 問題意識を持ち業務に 取り組むことができるようになる時期6でもあり,この 保健指導能力を必要と考える者が多くなったことが推測
される。

保健指導能力の修得度では，保健指導経験年数におい て,《生活習慣汇関する指導》や，《自立的な問題解決を促 す支援》を始めとする 10 項目で, 11 年以上の群が 5 年以 下の群よりも有意に点数が高いという結果であった。ま た，保健指導人数に打いて，《対象者のアセスメント》を 始めとする 5 項目で, 31 人以上の群が 0 人の群よりも有 意に点数が高いという結果であった．このことから，ア セスメントや対象に合わせた支援に関する保健指導能力 の修得には，保健指導の経験が関わっており，保健指導 の経験を重ねながら保健指導能力を修得していくことが 示唆された。

保健指導能力の修得意欲では, 保健指導人数において, 《生活習慣に関する指導》の〈対象者に合った身体活動・ 運動の改善が提示できる 1 項目において, 31 人以上の 群が 0 人の群よりも点数が有意に高いという結果であっ た。これは, 多くの対象者に保健指導を行う者ほど, 運動 に関する内容にふれる機会が多いことが推測され，運動 に関する保健指導能力を修得したいと考える者が多く なったのではないかと考える.

有意差がみられた保健指導能力に関しては, 経験年数 等の個人のレベルに応じた研修会プログラムの企画が望 まれる. 大西らが行った，特定保健指導実践者のスキル アップ研修の効果を検証した先行研究15においても, 保 健指導経験など参加者のレベルの差が研修会の課題とし てあげられていた。 保健指導の能力を強化するためには, 個人のレベルに合わせた研修と，自分自身で経験しなが ら能力を高めていくことを支援する必要性が示唆され た

\section{3. 研究の限界と今後の課題}

今回の調査では質問項目が 41 項目あり, 保健指導能 力の必要度, 修得度, 修得意欲の 3 つの調查を同時に 行ったため，回答する項目がかなり多くなってしまった， 今後は保健師からの意見聴取を行い, 質問内容の分かり にくい箇所を修正するとともに, 各項目の重要性や相違 性を検証し，質問数を絞り込んでいきたい．また，今回は 特定健康診查・保健指導の研修会会場にて質問紙を配布 した．研修会を受講している者としていない者とを区別 することなく分析対象としたため，研修会受講が能力の 必要度や修得意欲に影響を与元たことも考元られる.今 後は, 研修会参加による保健指導能力の認識の違いにつ いても検討を行っていきたい，そして，特定保健指導開 始から 3 年が経過したので, その後の評価も行っていき たい. 


\section{謝辞}

本調査にあたり，お忙しい中ご協力いただいた保健師 の皆様に深く感謝申し上げます。

本研究は, 2007 年度群馬パース大学特定研究費の助成 を受けて行ったものである.

\section{引用 文 献}

1. 厚生労働省健康局. 標準的な健診・保健指導プログラム (確定版). 2007.

2. 厚生労働大臣. 特定健康診査及び特定保健指導の適切か つ有効な実施を図るための基本的な指針. 2008.

3. 畧博, 馬場園明. 特定健康診査・特定保健指導に関するア ンケート調査結果. 日本公衆衛生雑誌 $2009 ; 56(6)$ ： 371-382.

4. 国民健康保険中央会. 第 7 回市町村国保に打ける特定健 診・保健指導に関する検討会会議資料特定健康診查・保 健指導の実施に関するワーキンググループ報告. 2010 ： 17-20.

5. 厚生労働省健康局. 健診・保健指導の研修ガイドライン (確定版). 2007 : 131-137.

6. Benner P (井部俊子, 井村真澄, 上泉和子訳) : ベナー看 護論一達人ナースの卓越性とパワー一第 1 版. 東京 : 医 学書院, $2003: 10-25$.

7. 佐伯和子, 和泉比佐子, 宇座美代子ら. 行政機関に働く保
健師の専門職務遂行能力の発達一経験年数群別の比較 一. 日本地域看護学会誌 $2004 ; 7(1) ： 16-22$.

8. 岡本玲子, 塩見美抄, 中山貴美子ら. 変換期に対応する保 健師の新たな専門技術能力獲得に関する研究. 平成 16 年 度厚生労働科学研究費補助金研究科学総合研究事業報告 書 2005: 106-130.

9. 舟島なをみ：第 2 章 院内教育プログラム立案・実施・評 価に必要な基礎知識. 舟島なをみ (編) : 院内教育プログ ラムの立案・実施・評価「日本型看護職者キャリア・ディ ベロップメント支援システム」の活用. 東京 : 医学書院, 2007 : 44.

10. 奥山則子: 第 1 章 保健指導の基本. 中村裕美子 (代): 標 準保健師講座 2 地域看護技術. 東京: 医学書院, 2005 : 6-12.

11. 宮本ふみ: 第 2 章 公衆衛生看護の中核をなす保健指導. 村嶋幸代 (編) : 最新保健学講座 3 地域看護支援技術. 東 京: メヂカルフレンド社, 2004: 17-19.

12. 厚生労働省健康局. 標準的な健診・保健指導プログラム (確定版). 2007 : 69.

13. 厚生労働省健康局. 標準的な健診・保健指導プログラム (確定版). 2007 : 82-87.

14. 宮㠃美砂子. これからの生活習慣病健診·保健指導の枠組 みでの保健師業務これからの保健師. からだの科学増刊 2006 : 62-65.

15. 大西美知恵, 越田美穂子, 片山陽子ら. 特定保健指導実践 者のスキルアップ研修の効果評価. 香川大学看護学雑誌 $2010 ; 14(1)$ : 47-56. 


\title{
Municipal Public Health Nurses' Perception of Capabilities Required for Health Guidance to Prevent the Metabolic Syndrome
}

\author{
Ikue Kiryu, ${ }^{1}$ Kazunari Kobayashi, ${ }^{2}$ Masae Yazima, ${ }^{2}$ \\ Ayumi Kobayashi, ${ }^{2}$ Ayako Ono ${ }^{2}$ and Yumi Sato $^{1}$ \\ 1 School of Health Science, Gunma University Faculty of Medicine, 3-39-22 Showa-machi, \\ Maebashi, Gunma 371-8511, Japan \\ 2 School of Nursing, Faculty of Health Science, Gunma Paz College, 1-7-1 Tonya-machi, \\ Takasaki, Gunma 370-0006, Japan
}

\begin{abstract}
Background/Objectives : This study aims to elucidate capabilities municipal public health nurses feel is required for health guidance, their acquisition status and the enthusiasm to acquire them. Subjects and Methods : A questionnaire was conducted in G prefecture of public health nurses with more than three years' experience in providing guidance on preventing metabolic syndrome. Forty-one items in six domains of health guidance capability were rated on a 5-point scale of necessity, achievement and enthusiasm. Results: Questionnaires were distributed to 281 nurses of whom 84 returned valid responses. Items of high necessity and enthusiasm were "Use of communication skills" and "support according to behavior modification stage," and items with low achievement were "development of teaching materials based on scientific evidence." Groups with more years of experience or more nurses with experience in providing preventative guidance scored higher in assessing subjects and providing guidance. Conclusion : It was suggested that to improve the ability of public health nurses to provide preventative guidance it is necessary to plan training sessions that focus on the above items with high necessity and enthusiasm, as well as items showing low achievement, and support public health nurses in consideration of experience, including health guidance. (Kitakanto Med J $2011 ; 61: 37 \sim 49$ )
\end{abstract}

Key words : public health nurse, metabolic syndrome, health guidance 